\title{
Immunofluorescence microscopy (IFM) analysis of primary ciliary dyskinesia $(P C D)$ patients with suspected inner dynein arm defects (IDA)
}

\author{
$\mathrm{R} \mathrm{Hjeij}^{1 *}$, NT Loges ${ }^{1}$, A Becker-Heck², H Omran ${ }^{1}$ \\ From First International Cilia in Development and Disease Scientific Conference (2012) \\ London, UK. 16-18 May 2012
}

Primary ciliary dyskinesia $(\mathrm{PCD})$, characterized by abnormal motility of cilia or flagella, is caused by defects of structural components such as inner dynein arms (IDAs). Recently high-speed videomicroscopy has substituted transmission electron microscopy (TEM) analysis as the "gold standard" for diagnosis. However, TEM is still the most widely used diagnostic tool in many countries. A recent study reported that isolated IDA defects is the most frequent $(>50 \%)$ ciliary defect in PCD, as detected by TEM (Theegarten, 2011). IFM analysis has shown in several studies that it can ascertain diagnosis such as in PCD variants caused by DNAH5, DNAI1, DNAI2, KTU, LRRC50, CCDC39 and CCDC40 mutations. IFM can provide a complete view of the ciliary axoneme and identify "partial" axonemal defects which may be misinterpreted by TEM (e.g. present in KTU mutant cilia). Here we performed IFM analysis of known PCD patients to identify the composition of dynein arm defects, including IDAs. Using antibodies specific to the IDA marker DNALI1, we determined that the frequency of isolated IDA defects is unexpected low (thus far, only 12 of $\sim 800$ PCD patients, $\sim 1.5 \%$ ). In contrast, we observe that IDA defects usually accompany DRC defects (absent/abnormal Gas11) or ODA defects (absent/abnormal DNAH5). Because the DNALI1 antibody is targeted against only 3 IDA isoforms out of 7 , we are currently screening additional IDAspecific antibodies for IFM analysis to target the other IDA sub-types which escaped our analysis. However, our results suggest the percentage of isolated IDA defects might be lower than previously expected.

* Correspondence: rim.hjeij@ukmuenster.de

${ }^{1}$ Universitätsklinikum Münster, Germany

Full list of author information is available at the end of the article

\section{Author details}

${ }^{1}$ Universitätsklinikum Münster, Germany. ${ }^{2}$ Department of Pediatrics, University Hospital Freiburg, Germany.

Published: 16 November 2012

doi:10.1186/2046-2530-1-S1-P23

Cite this article as: Hjeij et al:: Immunofluorescence microscopy (IFM) analysis of primary ciliary dyskinesia (PCD) patients with suspected inner dynein arm defects (IDA). Cilia 2012 1(Suppl 1):P23.

Submit your next manuscript to BioMed Central and take full advantage of:

- Convenient online submission

- Thorough peer review

- No space constraints or color figure charges

- Immediate publication on acceptance

- Inclusion in PubMed, CAS, Scopus and Google Scholar

- Research which is freely available for redistribution
C Biomed Central 